\title{
Influence of Control and Family Management in the Indebtedness of Brazilian Open Business: a Quantitative Study
}

\author{
Liliane Cristina Segura ${ }^{\dagger}$ \\ Universidade Presbiteriana Mackenzie \\ Henrique Formigoni ${ }^{\Omega}$ \\ Universidade Presbiteriana Mackenzie
}

\begin{abstract}
This research investigated the influence of the family on the debt of Brazilian open business companies. Although there is a vast national and international literature on capital structure, there are still doubts on the importance of family in business management. In Brazil, due to the large number of family businesses, it is even more evident the need to investigate the issue. The studied population was composed of companies listed on the BM\&FBovespa, in 2010, and the final sample consisted of 356 companies. Six years were analyzed (2004-2009), in a total of 2,136 observations. The results show that the studied companies that are familiar or that have family management have become less indebted than others. This result is in accordance with national and international studies, according to which family firms tend to be more conservative in their investments, seeking to use more equity than third party capital.
\end{abstract}

Keywords: Family business. Family management. Capital structure. Debt.

* Author for correspondence:

t. Doctorate in Management at Centro de Ciências Sociais e Aplicadas by Universidade Presbiteriana Mackenzie

Institution: Professor of the Graduation Course in Accounting at Universidade Presbiteriana

Mackenzie

Address: Rua da Consolação, 896, São Paulo

- SP - Brazil

E-mail: liliane.segura@mackenzie.br

Telephone: (11) 2114-8292

\author{
${ }^{\Omega}$ Doctorate in Accounting Sciences and \\ Controlling by Faculdade de Economia, \\ Administração e Contabilidade of the \\ Universidade de São Paulo. \\ Institution: Professor of Postgraduate Sensu \\ stricto program, Professional Masters in \\ Accounting, at Universidade Presbiteriana \\ Mackenzie \\ Address: Rua da Consolação, 896, São Paulo - SP - Brazil \\ E-mail: henrique.formigoni@mackenzie.br Telephone: \\ (11) $2114-8292$
}

Note from the editor: This article was accepted by Emerson Mainardes 


\section{INTRODUCTION}

he role played by families in company management has been studied extensively by various areas of management (FILATOTCHEV et al., 2005; DEDOUSSIS; PAPADAKI, 2010; MCCONAUGHY, 1994; MOSEBACH, 2007; BOUBAKARI; FEUDJO, 2010). Many of these studies, however, have been conducted only in small and medium companies that represent mostly, organizations with private and family control (LEAVELL; MANIAM, 2009; LANDSTROM; WINBERG, 2000).

In these studies, family and family member managers have obtained great prominence. Anderson and Reeb (2003), e.g., claim that 35\% of the 500 largest companies in the United States had, in some way, family influence. In Brazil, Oro et al. (2008) found that 253 companies, among the top 500 according to Exame magazine in 2005, had as characteristics the fully Brazilian stock control and $20 \%$ of these, approximately, operated under family interference. Unlike what the theory says about the separation between ownership and control (Jensen; Meckling, 1976; Berle; Means, 1932), there is, today, an extensive list of open capital companies that have family control through the directors or management board.

Other studies show that family business members (almost always) concentrate their wealth in one or a few firms (AGRAWAL; NAGARAJAN, 1990; ANDERSON; REEB, 2004; GÓMEZ-MEJÍA et al., 2007). However powdered capital, implicit or explicit in the finance theories (SOARES; KLOECKNER, 2008), is not the dominant form of ownership structure in Brazil (LA PORTA et al., 1999).

In the literature surveyed, it was not possible, however, find: i) work focused on financial decisions managers from the company's controlling family, and ii) the influence of the family in decision making.

In Brazil, although several studies have been developed about family businesses and the families' control in open companies, there is a lack of studies that relate the management of family members and the capital structure of companies.

In order to contribute to the existing researches on finance on capital structure and also on the family businesses management, it is intended to answer the following question: Is there any relation between family influence, family management and control on the indebtedness of Brazilian open companies? The general objective of this work is to verify if the level of debt 
of the companies under the influence of family management and control is different from those that have professional management.

The literature is not unanimous about these results, which justifies this study. Thus, this research helps to identify, in Brazil, which is the trend of indebtedness of family open companies.

This study includes, in addition to this introduction, the theoretical reference, followed by the methodology, analysis of results and final considerations.

\section{THEORETICAL REFERENCE}

According to Longenecker (2007, p. 82), family business is one in which two or more members of the same family are owners of a business or make management together or on succession. The company is recognized as a family business if it passes from one generation to another.

Oro et al. (2008, p. 3), by the way, made a theoretical review of the main classifications of family business and concluded that two characteristics are essential: the majority stake of the family in the company's capital family and family members in business management.

On this topic, Harris and Raviv (1991) presented a study highlighting the Agency Theory, which examines the conflict between the separation of ownership and management, by Jensen and Meckling (1976). Because of the importance of agency costs - existing costs because of the conflict between managers and owners -, other studies have emerged, such as Stulz (1990), which deals with conflicts between managers and owners; the Diamond (1989) and Hirshleifer and Thakor of (1993) dealing with the conflict between owners and creditors. These conflicts reflect a number of changes in capital structure and also explain the valuation of the company by its shareholders.

These works, we emphasize the fact that the capital structure is likely to change the value of the company and also its economic and financial performance. Thus, it is understood that those responsible for decisions regarding capital structure, the managers, forcefully influence on how such structure will be constituted.

Studies on family businesses have various fields such as: strategy (SIRMON; HITT, 2003; SIRMON et al., 2008), management conflicts (BORNHOLDT, 2005), behavior and organizational culture (KOTEY; MEREDITH, 1997; BERSON et al., 2005), financial and operational decisions (ANDERSON; REEB, 2003; 2004; ORO et al., 2008; BERTUCCI et al., 2009). 


\subsection{DEBT AND FAMILY}

The main aspect of this research, which obviously does not exhaust the possible discussions, concerns the consequent relation of actions of family and non-family members in a company: the debt.

If, on the one hand, some authors affirm that there is no relationship between debt and family control, on the other there are, in the literature, both advocates, that the relationship is positive as there is of negative relationship. Considering, therefore, roughly, three points of view: (a) there is a positive relationship; (b) there is a negative relationship; (c) there is no relationship.

Two of the authors to receive prominence for their research in this area are Schulze and Dino (2004). They identified in a sample of 1,000 observations that family businesses tend to have lower leverage, that is, have a lower debt than their non-family peers.

López-Gracia and Sánchez-Andújar (2007) also claim that there are differences between the financial decisions of family and non-family business. They found a lower level of debt in companies run by family members than in non-family businesses.

Pindado and La Torre (2008) found that managers of family businesses are more averse to risk than those of non-family businesses. Thus, the level of debt of family businesses tends to be lower than the non-family.

Also in this line, Al-Ajmi et al. (2009) concluded, from a sample of 53 Saudi companies, that the capital structure is positively influenced by concentrated ownership of pension funds and banks, but negatively related to family ownership. Firth (1995) also found high levels of debt in focused capital firms, result that shows that there are differences between business run by family members and companies in which the family is the majority shareholder.

Boubakari and Feudjo (2010) point to the fact that when the manager is a shareholder or member of the controlling family, the company tends to avoid debt, a negative relationship between debt and family manager, it indicates the contribution of the family manager as well as family property. Corroborating to these surveys is the most recent work of Lee (2011), which also identifies low leverage in companies that are subsidiaries of family businesses.

As opposed to the work described above, are the studies that show that there is a positive relationship between debt and family management or control. Andres (2009) studied a sample of 264 German companies and found that family businesses are more leveraged for 
resisting to seek financing through the issuance of shares. King and Santor (2008) also found greater leverage in the Canadian family businesses, an assessment of 613 family and nonfamily businesses. Leavell and Maniam (2009) show that, in small businesses in Texas, the owners prefer to increase the level of debt to finance their operations, rather than use the equity, thus increasing the level of corporate leverage.

There are other studies, such as Anderson and Reeb (2003), that examined 319 companies over a period of 6 (six) years and found no difference between the debt levels of family and non-family businesses. Likewise, in Brazil, the study of Machado et al. (2012), with companies listed on the BM\&FBovespa, indicates that there is no relationship between family management and debt.

As seen, the literature still unable to identify the influence of family, family manager and family control, as well as the founders on the company's debt.

\section{METODOLOGY}

This is a hypothetical deductive study, according to the fundamentals proposed by Popper (1975), as it is characterized by the establishment of hypotheses that must be tested through empirical research, that is, the observation of reality. The data treatment used for hypothesis testing was the econometric analysis by multiple regressions.

\subsection{POPULATION AND SAMPLE}

The set of observed companies was obtained from those that were active in the year 2010, the BM\&FBovespa list as well as the type of control of the company and the rating of corporate governance, totaling a population of 488 financial and non-financial companies. Were excluded those without the needed accounting data and also financial companies, by their peculiar characteristic of indebtedness to the research and thus a total of 356 companies wew analyzed, which constituted the final sample of this study, in a total of 2,136 observations.

\subsection{DATA COLLECTION}

Data on control and management were taken from DIVEXT, Divulgação Externa ITR/DFP/IAN of CVM. The names of shareholders and directors were collected from the annual information (IAN), which are required by the Brazilian open companies that trade their shares on BM\&FBovespa. Were collected all the names of the major shareholders (until the 5th largest shareholder), the percentage of common and preferred shares, the names of the Chairman of the Board, Chief Executive Officer and Chief Financial Officer from 2004 to 
2009. There were many companies that did not had data for all the observed years, therefore we chose to use an unbalanced panel.

\subsection{RESEARCH HYPOTHESES}

This research correlated different levels of debt with companies with family characteristics, family control and managed by family members separately.

\subsubsection{Family Business, Family Control And Debt}

From the point of view of family control in companies, the presence of a controlling shareholder reduces monitoring costs and agency conflicts, especially in environments with less legal and institutional protection to investors (OKIMURA, 2003; LA PORTA et al., 1999; DAMI et al., 2007).

The work of Gomes-Mejía et al. (2007), for example, shows evidence that the family managers are willing to increase the risk of the company to preserve their socioemotional wealth, even if it means higher debt and lower performance of the company. On the other hand, to Siqueira (1998, p. 11), firms with family control have a tendency to make investments with equity, reducing debt with third parties. This can occur because families are more conservative on their investments.

Some authors claim that there is a negative relationship between family and debt (SCHULZE; DINO, 2004; LÓPEZ-GRACIA; SÁNCHEZ-ANDÚJAR, 2007; PINDADO; LA TORRE, 2008; AL-AJMI et al., 2009; BOUBAKARI; FEUDJO, 2010; LEE, 2011); others indicate that there is a positive relationship between family and debt (ANDRES; 2009, KING; SANTOR, 2008; LEAVELL; MANIAN, 2009), and finally, some authors indicate no relationship between family and debt (MACHADO et al., 2012; ANDERSON E REEB; 2003).

Therefore, it is noted, that studies involving family businesses are diverse and controversial. At the same time, these studies sometimes treat family control, sometimes only the description of family business, and other times, the family in the management or in company's stock. Hence, in this article, companies were classified as: family businesses (two or more directors of the same family in the administration of the company or two or more directors of the same family who own shares in the company - regardless of the number of shares) and also family-controlled companies (businesses classified as family business, and also those in which family shareholders own more than $50 \%$ of the company's shares). 
In order to test more fully the relationship of the family with the debt the following hypotheses were formulated:

$H_{1}$ : There is a relationship between family business and indebtedness of the Brazilian open businesses companies.

$\mathrm{H}_{2}$ : There is a relationship between family control and the indebtedness of the Brazilian open businesses.

\subsubsection{Management of the Controlling Family and Indebtedness}

Consistently with the hypotheses presented above, one would expect there to be different decision makings, if there are family members in management.

Shleifer and Vishny (1986) point as one of the biggest costs of a familiar management the non-diversification of investments, due to risk aversion. Anderson and Reeb (2003) corroborate this statement, indicating that the family can avoid the risk in two ways: through diversification of their projects or through support in self-financing, as it would diminish the indebtedness of companies.

Barros (2005, p. 41) lists a series of surveys that have been applied to managers and demonstrates the behavioral biases of overconfidence and optimism. It is possible to understand that, without the risk of job loss, the manager, member of the owning family, would assume greater risks, and therefore, more debt. It is also possible that, for fear of loss of power in the family business, the manager use riskier strategies, for example, increase in indebtedness (GOMES-MEJÍA et al., 2007).

In agreement with the theories developed to highlight the agency conflict, Friend and Hasbrouck (1987) claim that the capital structure of the company is determined, mostly, by the interest of managers, even if it is in conflict with the wishes of shareholders. This helps to explain the need that the shareholders have to control the main managers of the companies.

However, as Friend and Lang (1988) explain, increasing the debt with third parties helps to discipline management and reduces the agency conflict. Thus, it is expected that companies with professional managers possess higher level of debt with third part companies than companies with family founding members managers. For family management, were considered all family businesses that had also family members in positions of command in the company, regardless of whether shareholder control is involved. Facing it, a new hypothesis must be considered: 
H3: There is a relationship between family management and the indebtedness of the Brazilian open businesses companies.

\subsection{DEFINITIONS OF THE STUDY VARIABLES}

The variables used in this study were taken from studies on capital structure both national and international. The work of Forte (2005), Brito et al. (2007), Soares and Kloeckner (2008), Perobeli et al. (2005), Barros (2005), Anderson and Reeb (2003) were the basis to seek the necessary variables, since they are works developed with Brazilian companies.

\subsubsection{Dependent or Explained Variables}

The dependent variable consists of indebtedness $\left(\right.$ End $\left._{\mathrm{i}, \mathrm{t}}\right)$ of the company in its various forms. For this, four dependent variables were tested: Total Debt, Financial Debt, Short-Term Debt and Long Term Debt, as are described below:

\subsubsection{Total Indebtedness (ET)}

The variable used to total indebtedness was composed of:

$$
E T_{\mathrm{i}, \mathrm{t}}=\frac{\mathrm{PC}_{\mathrm{i}, \mathrm{t}}+\mathrm{PNC}_{\mathrm{i}, \mathrm{t}}}{\mathrm{AT}_{\mathrm{i}, \mathrm{t}}}
$$

Where: $\mathrm{ET}_{\mathrm{i}, \mathrm{t}}=$ Total indebtedness of firm $i$, in the year $t ; \mathrm{PC}_{\mathrm{i}, \mathrm{t}}=$ current liabilities of firm $i$, in the year $t$; $\mathrm{PNC}_{\mathrm{i}, \mathrm{t}}=$ Non-current liabilities of firm $i$, in the year $t$ e $\mathrm{AT}_{\mathrm{i}, \mathrm{t}}=$ Total assets of company $i$, in year $t$.

\subsubsection{Financial Indebtedness (Efin)}

The financial indebtedness was treated by several authors as a means to leverage the company (BARROS, 2005; FORTE, 2005; ANDERSON; REEB, 2003). The calculation is represented as follows:

$$
\operatorname{Efin}_{i, t}=\frac{F C P_{i, t}+F L P_{i, t}}{A T_{i, t}}
$$

Where: Efin $_{\mathrm{i}, \mathrm{t}}=$ Financial indebtedness of the firm $i$ (including commercial papers and bonds, excluding debentures), in te year $t ; \mathrm{FCP}_{\mathrm{i}, \mathrm{t}}=$ Financing with financial institutions for short-term of the firm $i$, in the year $t ; \mathrm{FLP}_{\mathrm{i}, \mathrm{t}}=$ Financing with financial institutions for longterm of the firm $i$, in the year $t$ e $\mathrm{AT}_{\mathrm{i}, \mathrm{t}}=$ Total assets of the firm $i$, in the year $t$.

\subsubsection{Short-term indebtedness (ECP)}

The short-term indebtedness measures the debts incurred by the company, whether as their accruals, whether due to short-term financing. 


$$
\mathrm{ECP}_{\mathrm{it}}=\mathrm{PC}_{\mathrm{it}} / \mathrm{AT}_{\mathrm{it}}
$$

Where: $\mathrm{ECP}_{\mathrm{i}, \mathrm{t}}=$ Short-term indebtedness of the firm $i$, in the year $t ; \mathrm{PC}_{\mathrm{i}, \mathrm{t}}=$ Current liabilities of the firm $i$, in the year $t ; \mathrm{AT}_{\mathrm{i}, \mathrm{t}}=$ Total assets of the firm $i$, in the year $t$.

\subsubsection{Long-term indebtedness (ELPAT)}

Was comprised of:

$$
E L P A T_{\mathrm{i}, \mathrm{t}}=\frac{P N C_{\mathrm{i}, \mathrm{t}}}{A T_{i, t}}
$$

Where: $\mathrm{ELPAT}_{\mathrm{i}, \mathrm{t}}=$ Long-term indebtedness of the firm $i$, in the year $t$.

\subsection{INDEPENDENT OR EXPLANATORY VARIABLES}

These variables were obtained from the annual information report of companies (IAN), issued by CVM, in the Divext system.

\subsubsection{Variable for definition of family business (FAM)}

Were considered to family involvement in business, the following characteristics: a) two or more members of the same family are in the directory or on the company board; b) two or more members of the same family own shares of the company, among the five largest shareholders; and / or c) the company is controlled by a family holding, dummy variable, where Fam $=1$ if the company is familiar; and Fam =0, otherwise.

\subsubsection{Variable for definition of family control (Cfam)}

Family-controlled companies are those classified as family businesses, according to item 3.5.1 and also have more than $50 \%$ of the common shares of the company. These companies do not necessarily have a family management. The family may control the company but do not get involved with the management, that is, there is no family in positions of CEO, CFO or PCA. Dummy variable, where CFAM = 1 if the company is family control; and $\mathrm{CFAM}=0$ otherwise.

\subsubsection{Variable for definition of family management (Gfam)}

It is a combination of firms classified as family business and the ones that have family shareholders in one of the positions of CEO, Chairman of the Board of Directors and/or Chief Financial Officer. Dummy variable where 1 = Gfam if there is family management; and Gfam $=0$ otherwise. 


\subsection{CONTROL VARIABLES}

\subsubsection{Profitability $\left(L_{U C R}, t\right)$}

The profitability of a company is much discussed in the work on capital structure as an important factor to seek or not new financing. Greater profitability may indicate lower level of debt with third parties (MYERS, 1984; MOREIRA; PUGA, 2000; BRITO et al., 2007; SOARES; KLOECKNER, 2008; PEROBELI et al., 2005).

$$
L U C R_{i, t}=\frac{L O_{i, t}}{A T_{i, t}}
$$

Where: $\mathrm{LUCR}_{\mathrm{i}, \mathrm{t}}=$ Profitability of the firm $i$, in the year $t ; \mathrm{LO}_{\mathrm{i}, \mathrm{t}}=$ Operational profitability before Financial Result (and before taxes) of the firm $i$, in the year $t$.

\subsubsection{Growth opportunity $\left(O P C R_{i, t}\right)$}

Can be one of the reasons why the company borrows more money, increasing the indebtedness (HEINEBERG; PROCIANOY, 2003; PEROBELI et al., 2005; SOARES; KLOECKNER, 2008). It was used by Barros (2005) as an alternative proxy to growth opportunity.

$$
V A T_{i, t}=A T_{i, t} / A T_{i, t-1}
$$

Where: $\mathrm{VAT}_{\mathrm{i}, \mathrm{t}}=$ variability of the total assets of the firm $i$, in the year $t ; \mathrm{AT}_{\mathrm{i}, \mathrm{t}-1}=$ Total assets of the firm $i$, in the year $t-1$.

\subsubsection{Company Size}

This variable was used in several studies (ZAHA, 2010; MINICHILINI et al., 2010; SOARES; KLOECKNER, 2008, PEROBELI et al., 2005). The larger the company size, the higher its indebtedness. Company size is measured by the variable LNAT $_{\mathrm{i}, \mathrm{t}}=$ neperian logarithm of total assets of the firm $i$, in year $t$.

\subsubsection{Risk (Risk $\left.\mathrm{i}_{\mathrm{i}}\right)$}

It was used in several studies (SOARES; KLOECKNER, 2008; PEROBELI et al., 2008; GOMES-MEJÍA et al., 2008). The undiversified risk of the managers is defined by Friend and Lang (1988) as the standard deviation of operational income (before interest and taxes) divided by total assets, which is used as a proxy for risk.

$$
\text { Risk }_{i, t}=\text { desvio padrão } \frac{L O_{i, t}}{A T_{i, t}}
$$

Where: $\operatorname{Risk}_{\mathrm{i}, \mathrm{t}}=$ Risk of the firm $i$, in year $t ; \mathrm{LO}_{\mathrm{i}, \mathrm{t}}=$ operational income of the firm $i$, in year $t$; and Desvio-Padrão = standard deviation of the variables LO and AT in the last 5 years. 


\subsubsection{Tangibility (Tangi,t)}

Tangibility is another factor that causes the indebtedness of companies (BREALEY et al., 2008).

$$
\operatorname{Tang}_{i t}=\frac{I_{i, t}}{A T_{i, t}}
$$

Where: Tang $_{\mathrm{i}, \mathrm{t}}=$ tangibility of the firm $i$, in the year $t ; \mathrm{I}_{\mathrm{i}, \mathrm{t}}=$ net fixed assets of the firm $i$, in year $t$.

\subsubsection{Free Cash Flow (FLCL $\left.L_{i, t}\right)$}

It is a factor that can reduce the debt of the companies (JENSEN, 1986; SOARES; KLOECKNER, 2008; PEROBELLI et al., 2005), that is, firms with higher free cash flow are less indebted. This happens because companies that have money to invest do not have the tendency to seek for financing.

$$
F L C L_{i, t}=\mathrm{LL}_{\mathrm{i}, \mathrm{t}}-\text { AumentoCGL }_{\mathrm{i}, \mathrm{t}}+\text { Depr }_{\mathrm{i}, \mathrm{t}}-\text { Invest }_{\mathrm{i}, \mathrm{t}}
$$

Where: FLCL $\mathrm{L}_{\mathrm{i}, \mathrm{t}}=$ free cash flow of the firm $i$, in the year $t ; \mathrm{LL}_{\mathrm{i}, \mathrm{t}}=$ net profit of the firm $i$, in the year $t$; AumentoCGL $\mathrm{L}_{\mathrm{i}, \mathrm{t}}=$ increase in net working capital of the firm $i$, calculated as the difference of the CCL (net working capital) of the firm $i$, in the year $t-1$ and year $t$; Depr $_{\mathrm{i}, \mathrm{t}}=$ depreciation of the firm $i$, in the year $t$ and Invest $\mathrm{i}_{\mathrm{i}, \mathrm{t}}=$ investments of the firm (composed by the variation of asset) $i$, in the year $t$.

\subsubsection{Other extra debt tax benefits $\left(O B E N_{i, t}\right)$}

As a measure of control it will be used the extra debt tax benefits, which includes all expenses not related to the debts of the company, but that may influence the indebtedness (BARROS, 2005).

$$
O B E N_{i t}=\frac{\text { Deprec }_{i, t}+\text { Amort }_{i, t}}{A T_{i, t}}
$$

Where: $\mathrm{OBEN}_{\mathrm{i}, \mathrm{t}}=$ Other tax benefits of the firm $i$, in the year $t$; Deprec $\mathrm{i,t}=$ Depreciation expense of the firm $i$, in the year $t$; Amort $\mathrm{i}_{\mathrm{i}, \mathrm{t}}=$ Amortization expense of the firm $i$, in the year $t$.

\subsubsection{Sales growth $\left(\mathrm{CVEN}_{\mathrm{i}, \mathrm{t}}\right)$}

Indicates increased financing for the need of growth (BRITO ET AL., 2007). To make a comparison between sales growth for family and non-family businesses indicates, in some way, that there are decisions to seek money in different ways (FAMA; FRENCH, 2002). 


$$
C V E N_{i, t}=\frac{R L V_{i, t}}{R L V_{i, t-1}} \times 100
$$

Sendo: $\mathrm{CVEN}_{\mathrm{i}, \mathrm{t}}=$ sales growth of the firm $i$, in the year $t ; \mathrm{RLV}_{\mathrm{i}, \mathrm{t}}=$ net sales revenues of the firm $i$, in the year $t$; $\operatorname{RLV}_{\mathrm{i}, \mathrm{t}-1}=$ net sales revenues of the firm $i$, in the year $t-1$.

\subsubsection{Governance (GovI)}

The level of governance was used as a measure of influence on capital structure by several authors (PEROBELLI et al., 2002; PEROBELLI et al., 2005; SILVEIRA, 2004). It is a dummy variable to identify the level of governance established by BM\&FBovespa. It was considered that companies with the highest level of corporate governance are those classified only as Level 2 or Novo Mercado by BM\&FBovespa. (Level 2 and Novo Mercado = 1, other $=0$ levels).

\subsubsection{Debentures $\left(\right.$ Deb $\left._{\mathrm{i}, \mathrm{t}}\right)$}

Values of debentures issued during the period analyzed were collected as the amount issued could in some way influence the indebtedness of the company. This variable represents the exact constant value on account of long-term debentures of the analyzed company.

\subsubsection{Activity Sector}

The company's activity was identified by a dummy according to the sector in which it operates $(1=$ yes, operates in the sector, $0=$ no, does not operate in the sector $)$.

\subsubsection{Year}

The year was identified by dummies to capture any macroeconomic shocks and possible temporal effects that can affect all companies (BARROS, 2005). The year dummies are binary variables represented by 0,1 , where $t=1$ in the year observed for the firm $i$, and, otherwise $\mathrm{t}=0$.

It is important to note that there was no specific control in relation to changes in accounting standards (IFRSs) which began in 2008, for a few specific reasons: a) the companies were only required to submit the financial statements from 2010 - despite having knowledge that many published prior to the scheduled date; b) according to the studies of Martins and Paulo (2010) and Tonetto Filho and Fregonessi (2010) showed no significant changes in the levels of indebtedness of Brazilian companies. 


\subsection{ECONOMETRIC MODELS}

\subsubsection{Family business and indebtedness}

The model used to evaluate the hypothesis H1, family business and indebtedness is specified in equation:

$$
E n d_{i t}=\beta_{0}+\beta_{1} F_{a m}+\sum_{j=1}^{k} \delta_{j} V C_{j i t}+\varepsilon_{i t}
$$

Where: End $_{i t}$ is the indebtedness of the company; Fam $i t$ represents the presence of the family on the company; $\mathrm{VCj}_{i t}$ are the control variables and $\varepsilon_{\mathrm{it}}$ is the error.

\subsubsection{Family control and indebtedness}

The model that evaluated the hypothesis $\mathrm{H} 2$, family control and indebtedness is specified in the equation:

$$
\operatorname{End}_{i t}=\beta_{0}+\beta_{1} \text { Cfam }_{\mathrm{it}}+\sum_{j=1}^{k} \delta_{j} V C_{j i t}+\varepsilon_{i t}
$$

Where: End $\mathrm{it}_{\mathrm{t}}$ is the indebtedness of the company; $\mathrm{Cfam}_{i t}$ represents the control of the family on the company; $\mathrm{VCj}_{i t}$ are the control variables and $\varepsilon_{\mathrm{it}}$ is the error.

\subsubsection{Family management and indebtedness}

The model that evaluated the hypothesis H3, family management and indebtedness, is specified in equation:

$$
\text { End }_{i t}=\beta_{0}+\beta_{1} \text { Gfam }_{\mathrm{it}}+\sum_{j=1}^{k} \delta_{j} V C_{j i t}+\varepsilon_{i t}
$$

Where: End ${ }_{i t}$ is the indebtedness of the company; GFam $i t$ represents the management or not of controllers; $\mathrm{VCj}_{i t}$ are the control variables and $\varepsilon_{i t}$ is the error.

\section{ANALYSIS OF RESULTS}

\subsection{DESCRIPTIVE ANALYSIS}

Were analyzed 356 businesses during six years (2004-2009). Companies analyzed were classified by sectors, as shown on Table 1 . 
Table 1 - Distribution of the sample by sector

\begin{tabular}{|c|c|c|}
\hline Sector & Number & Percentage \\
\hline Oil and Gas & 5 & $1.40^{\circ} \%$ \\
\hline Electricity & 45 & $12.64 \%$ \\
\hline Trausportation & 18 & $5.06 \%$ \\
\hline$\overline{\text { Construction }}$ & 30 & $8.43 \%$ \\
\hline Agriculture & 5 & $1.40 \%$ \\
\hline Mining & 8 & $2.25 \%$ \\
\hline Food and Beverage & 20 & $5.62 \%$ \\
\hline Textiles & 29 & $8.15 \%$ \\
\hline Trade & 18 & $5.06 \%$ \\
\hline Industrial Machinery & 5 & $1.40 \%$ \\
\hline Investment Funds & 1 & $0.28 \%$ \\
\hline Telecommunications & 14 & $3.93 \%$ \\
\hline Electronics & 7 & $1.97 \%$ \\
\hline$\overline{\text { Vehicles and Parts }}$ & 18 & $5.06 \%$ \\
\hline Non-Metallic Minerals & 4 & $1.12 \%$ \\
\hline Paper and Cellulose & 5 & $1.40 \%$ \\
\hline Others & 81 & $22.75 \%$ \\
\hline Chemical Industry & 14 & $3.93 \%$ \\
\hline Steel \& Metals & 25 & $7.02 \%$ \\
\hline Soffware and Data & 4 & $1.12 \%$ \\
\hline Total & 356 & $100.00 \%$ \\
\hline
\end{tabular}

Source: survey data

The sample is distributed in 20 sectors. It was used the classification of Bovespa. The most representative is the sector of Electricity (12.64\%), followed by Construction $(8.43 \%)$, Textiles (8.15\%) and Steel \& Metals (7.02\%).

Data analysis identifies in the sample that $29.54 \%$ companies have family characteristics, as shown in Table 2. It is important to note that some companies that have been classified in previous years as family, ceased to be so during the observed period. This is also important for the observed data, since the characteristics of debt may have changed when changing the type of company.

Table 2 - Family Business

\begin{tabular}{lrc}
\hline Type of company & Total obs & \% obs \\
\hline Family Business & 631 & $29.54 \%$ \\
\hline Non-Family Business & 1505 & $70.46 \%$ \\
\hline Total & 2136 & $100.00 \%$ \\
\hline
\end{tabular}

Source: survey data. 
Among the family businesses, it was observed that $64.98 \%$ of them are controlled by a family, according to Table 3 . This means that the family also owns over $50 \%$ of the company shares.

Table 3 - Type of control in family businesses

\begin{tabular}{lcc}
\hline \multicolumn{1}{c}{ Type of Control } & Total obs & \% obs \\
\hline Family control & 410 & $64.98 \%$ \\
\hline No family control & 221 & $35.02 \%$ \\
\hline Total & 631 & $100.00 \%$ \\
\hline Source: survey data & &
\end{tabular}

Although a portion (35.02\%) of family businesses is not controlled by the family through shares, it is observed, in Table 4 , that $93.19 \%$ of family businesses are managed by family members. This indicates the great influence of the family in the management of companies, even if it has no controlling interest.

Table 4 - Type of management in family businesses

\begin{tabular}{lrr}
\hline Type of management & Total obs & \% obs \\
\hline Family management & 588 & $93.19 \%$ \\
\hline professional management & 43 & $6.81 \%$ \\
\hline Total family members & 631 & $100.00 \%$ \\
\hline Source: survey data & &
\end{tabular}

Once the variables were analyzed for all companies in the sample (familiar and nonfamiliar), it was decided to analyze the mean and standard deviation of the set of observed companies. Table 5 shows the descriptive statistics, the mean, standard deviation and median for all variables observed in this study. The variables are already winsorized so that the outliers do not influence the presented results.

Table 5 - Descriptive statistics of family and non-family businesses

\begin{tabular}{|c|c|c|c|c|c|c|}
\hline \multirow[b]{3}{*}{ Variable } & \multicolumn{3}{|c|}{ Xon-family } & \multicolumn{3}{|c|}{ Family } \\
\hline & \multicolumn{3}{|c|}{ standard } & \multicolumn{3}{|c|}{ Standard } \\
\hline & Mean & Deviation & Median & Meati & Deviation & Median \\
\hline Long-term indebtedness & 0.39 & 0.4 & 0,3 & 0,37 & 0,36 & 0.29 \\
\hline Financial Indebtedness & 0,34 & 0,25 & 0.27 & 0,37 & 0.25 & 0.3 \\
\hline Short-term indebtedness & 0.2 & 0.17 & 0.19 & 0.23 & 0.17 & 0.22 \\
\hline Total Indebtedness & 0,15 & 0.11 & 0.13 & 0.12 & 0.1 & 0.1 \\
\hline Profitability & 0,14 & 0,17 & 0,08 & 0,11 & 0,13 & 0.07 \\
\hline Size (LNREC) & 13.26 & 2 & 73.59 & 12,72 & 187 & 12,77 \\
\hline Risk (RISK) & 0.09 & 0,12 & 0,05 & 0,08 & 0.71 & 0.04 \\
\hline Tangibility (TANG) & 0.33 & 0,24 & 0.33 & 0.32 & 0.23 & 0.33 \\
\hline Growth Opportunity (OPCR) & 1.63 & 1,93 & 0,99 & 1.52 & 1.83 & 0,9 \\
\hline Sales Growth (CVEN) & 0.15 & 0,32 & 0,1 & 0,15 & 0,32 & 0.08 \\
\hline Free Cash Flow $(\mathrm{FLCL})^{\cdots}$ & 103,71 & $384,+6$ & 15.35 & 351 & 200.95 & 10.85 \\
\hline Other Tax Benefits (OBEN] & 0,32 & 0,53 & $\theta$ & 0.33 & 0,6 & $=$ \\
\hline Debentures Value (Deb) ${ }^{27}$ & 144.78 & 309.03 & 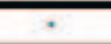 & 102.94 & 249.34 & 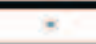 \\
\hline
\end{tabular}


In Table 5, is possible to observe a slight tendency for the total and long-term indebtedness in family businesses to be smaller. It is also possible to identify a lower mean of free cash flow and lower issuance of debentures.

\subsection{ANALYSIS OF RESEARCH RESULTS}

To decide between the best regression method to be applied to the panel data, we used the Hausman test. The Hausman test checks which of the two models (fixed or random effects) is appropriate to the sample. This test gave a result of Prob $>$ Chi2 of 0.000 , which means that there are differences in estimation between the two tests applied and the best to use is the Fixed Effects. Therefore, it was used the treatment by fixed effects for the results presented.

As shown in Table 6, the total indebtedness and also the short-term indebtedness have negative and significant relationship with the family business. This means that there is a relationship between family businesses and indebtedness and family businesses, in the selected sample, had total indebtedness and lower short-term indebtedness than non-family businesses. It cannot be said, however, that there is a relationship between long-term indebtedness or financial indebtedness with the family business observed in the sample.

Table 6- Regression for family businesses

\begin{tabular}{|c|c|c|c|c|c|}
\hline \multicolumn{2}{|c|}{ Independent Variables } & \multicolumn{4}{|c|}{ Dependent Variables } \\
\hline & & ET & ERPAT & ECP & Efin \\
\hline \multirow[t]{2}{*}{ Fanily Business } & Fam & $-0,408 \% *$ & 0,077 & $-0,346 * * *$ & 0.020 \\
\hline & enor & 0.185 & 0.124 & 0.092 & 0.082 \\
\hline \multirow[t]{2}{*}{ Governance } & GOV & 0,479 & $-0,131$ & 0,041 & 0,041 \\
\hline & entor & 0.238 & 0.160 & 0,117 & 0.107 \\
\hline \multirow[t]{2}{*}{ Profitability } & LUCR & $0,295 * *$ & $0,144 *$ & 0,025 & $-0,060$ \\
\hline & enor & 0.127 & 0.0856 & 0.063 & 0,057 \\
\hline \multirow[t]{2}{*}{ Company Size } & LNAT & $-0,156 \% *$ & $-0,015$ & $-0,100 * * *$ & $0,0,36 * *$ \\
\hline & error & 0.036 & 0.024 & 0.019 & 0.016 \\
\hline \multirow[t]{2}{*}{ Risk } & RISK & 1,121 ** * & $0,544^{\text {kw * }}$ & $0,304^{t * t}$ & $-0,0127$ \\
\hline & error & 0.204 & 0.137 & 0,101 & 0.092 \\
\hline \multirow[t]{2}{*}{ Tangibility } & TANG & $0,454 * t+\pi$ & $0,301 * * *$ & -0.089 & $0,261^{+\infty}$ \\
\hline & enor & 0,134 & 0,089 & 0,069 & 0.060 \\
\hline \multirow[t]{2}{*}{ Growth Opportunity } & OPCR & $-0,014^{t *}$ & $-0,007$ & $-0,001$ & 0,003 \\
\hline & enror & 0.006 & 0.004 & 0.003 & 0,002 \\
\hline \multirow[t]{2}{*}{ Sales growth } & CVEN & $0,1.39 * * *$ & 0,0396 & $0,063 * * *$ & -0.0145 \\
\hline & error & 0.415 & 0.0279 & 0.021 & 0.0186 \\
\hline \multirow[t]{2}{*}{ Free Cash Flow } & FLCL & 0,000 & $0,000^{\text {t }}$ * $\mathrm{k}$ & $0,000^{\text {*** }}$ & 0,000 \\
\hline & stror & 0.000 & 0.000 & 0.000 & 0.000 \\
\hline \multirow[t]{2}{*}{ Other Tax Benefits } & OBEN & 0,022 & $0,030^{*}$ * & $-0,020^{*}$ & 0,004 \\
\hline & eiror & 0,024 & 0.016 & 0.012 & 0.0109 \\
\hline \multirow[t]{2}{*}{ Payout } & Pout & 0,000 & $-0,0003$ & $0,0003 *$ & 0,000 \\
\hline & enor & 0,000 & 0,000 & 0,000 & 0000 \\
\hline \multirow[t]{2}{*}{ Debentures } & Deb & 0,000 & 0,000 & $\mathbf{0 , 0 0 0}$ & 0,000 \\
\hline & enor & 0.000 & 0.000 & 0,000 & 0.000 \\
\hline \multicolumn{2}{|l|}{ Year Dumuny } & YES & YES & YES & YFS \\
\hline R-squared & $\mathrm{R}^{2}$ & 0,342 & 0,216 & 0,257 & 0,02 \\
\hline
\end{tabular}

The bold values mean coefficient (estimator) obtained by regression and the standard error is shown in the following line. In terms of statistical significance, is presented: $* * *$ at the level of $1 \%$; ** at the level of $5 \%$ and $*$ at the level of $10 \%$. 
It was also observed a positive and significant relationship between profitability, risk, tangibility, sales growth and the indebtedness of the company. This means that these variables are related to the increase in indebtedness. It was also found a negative and significant relationship between growth opportunity, company size and indebtedness, indicating that they contributed to the decrease in indebtedness of the observed companies.

No significant relationship between family control and indebtedness were found. Thus, it was decided to remove this table from this study.

In respect to family management, relations were also identified by regression. It can be argued that there is a negative and significant relationship between the levels of total indebtedness, long term-indebtedness and short-term indebtedness of family businesses. This means that companies run by family members presented, in general, lower indebtedness than non-family businesses, as shown in Table 7.

Table 7 - Regression for family management

\begin{tabular}{|c|c|c|c|c|c|}
\hline \multicolumn{2}{|c|}{ Independent Variables } & \multicolumn{4}{|c|}{ Dependent Variables } \\
\hline & & ET & ELPAT & ECP & Efin \\
\hline \multirow[t]{2}{*}{ Family Management } & Gfam & $-0,267 *$ & $-0,246 \div \div$ & $-0119^{*}$ & 0,046 \\
\hline & error & 0,138 & 0,091 & 0,069 & 0,061 \\
\hline \multirow[t]{2}{*}{ Governance } & GOV & 0,0442 & $-0,011$ & 0,038 & 0,041 \\
\hline & error & 0,239 & 0,159 & 0,119 & 0,107 \\
\hline \multirow[t]{2}{*}{ Profitability } & LUCR & $0,269 * *$ & 0,091 & 0,026 & $-0,052$ \\
\hline & error & 0,130 & 0,086 & 0,065 & 0,058 \\
\hline \multirow[t]{2}{*}{ Company Size } & $\overline{\text { LNAT }}$ & $-0,157 * *$ & $-0,019$ & $-0,098 * *$ & $0,036 * *$ \\
\hline & error & 0,036 & 0,024 & 0,019 & 0,016 \\
\hline \multirow[t]{2}{*}{ Risk } & RISK & $1,206 * *$ & $0,435 * *$ & $0,407 * *$ & $-0,006$ \\
\hline & error & 0,194 & 0,129 & 0,097 & 0,087 \\
\hline \multirow[t]{2}{*}{ Tangibility } & TANG & $0,433 * *$ & $0,262 * * *$ & $-0,096$ & $0,267 * * *$ \\
\hline & error & 0,135 & 0,090 & 0,070 & 0,060 \\
\hline \multirow[t]{2}{*}{ Growth Opportunity } & OPCR & $-0,013 * *$ & $-0,007$ & $-0,001$ & 0,002 \\
\hline & error & 0,007 & 0,004 & 0,003 & 0,003 \\
\hline \multirow[t]{2}{*}{ Sales growth } & CVEN & $0,138 \div$ & 0,037 & $0,063 \div *$ & $-0,014$ \\
\hline & error & 0,041 & 0,027 & 0,022 & 0,018 \\
\hline \multirow[t]{2}{*}{ Free Cash Flow } & FLCL & 0,000 & $0,000 \div \div$ & $0,000 \div \div$ & 0,000 \\
\hline & error & 0,000 & 0,000 & 0,000 & 0,000 \\
\hline \multirow[t]{2}{*}{ Other Tax Benefits } & OBEN & 0,021 & $0,029 *$ & $-0,020 *$ & 0,000 \\
\hline & error & 0,024 & 0,016 & 0,012 & 0,000 \\
\hline \multirow[t]{2}{*}{ Payout } & Pout & 0,000 & $-0,000$ & 0,000 & 0,000 \\
\hline & error & 0,000 & 0,000 & 0,000 & 0,000 \\
\hline \multirow[t]{2}{*}{ Debentures } & Deb & 0,000 & 0,000 & 0,000 & 0,000 \\
\hline & error & 0,000 & 0,000 & 0,000 & 0,000 \\
\hline \multicolumn{2}{|l|}{ Year Dummy } & YES & YES & YES & YES \\
\hline R-squared & $\mathrm{R}^{2}$ & 0,359 & 0,224 & 0,381 & 0,186 \\
\hline
\end{tabular}

In terms of statistical significance, is presented: *** at the level of $1 \% ; * *$ at the level of $5 \%$ and $*$ at the level of $10 \%$.

The regression has robust standard errors, clustered by company. 
These results are consistent with studies of Zurich (2005), Lee (2011), Oro et al. (2009) and also with the Burkart et al. (2003) that, in general, claim that the monitoring by the family makes managers seek lower indebtedness in companies. The results are also consistent with the work of Schulze and Dino (2004) and López-Gracia and Sánchez-Andújar (2007), and Pindado and La Torre (2007), Al-Ajmi et al. (2009), Boubakari and Feudjo (2010) and Lee (2011). But these results are not compatible with the studies of Fiegenbaum and Thomas (1988), Landstrom and Winberg (2000), Leavel and Maniam (2009), Andres (2009), King and Santor (2008) show that family businesses seek greater external indebtedness than the others, because of the fear of loss of business when issuing shares. The studies of Anderson and Reeb (2003) also found no relationship between family business and indebtedness.

Of all presented results, the only independent variable that was not statistically significant was the family control. Other relationships proposed statistical significance, that is, there are indications that there is a relationship between indebtedness and family business and family management.

Regarding the behavioral aspect, treated by many researched works, including Barros (2005), Malmendier and Tate (2004), Thaler and Barberis (2003), the statistical analysis used in the observed sample showed no increase in indebtedness for the founding managers, as evidenced in the work of Barros (2005), with Brazilian companies. This result is not necessarily a surprise, because it is already known that there are wide ranges of variables to consider in an analysis of this particular type of company.

The research also revealed that some of the behaviors described in the literature can be seen in the obtained results, but not necessarily all. The fact that the family member managers with share concentration tend to debt could be explained by overconfidence (BARROS, 2005). At the same time, the family member managers with dispersed stock could also tend to escape from indebtedness.

\section{FINAL CONSIDERATIONS}

Several studies have exposed the cognitive biases of managers in companies around the world. These studies have also shown a series of classifications and results that differ from each other and make it difficult to interpret the relationship between family, managers and controllers with the indebtedness of the company.

These results imply, roughly, the fact that the control of variables involving the study on the participation of managers and their nature - family members or not, concentrated or 
dispersed control etc. - Is complex and often leads to results that are not always consistent with those already found in the specific literature. It implies also, of course, the need for more studies in conditions varying from those used in this study, since the topic is rich and broad.

This study contributes to the literature of Finance through empirical research on companies listed on the BM\&FBovespa. It was sought to study the relationship between family business, family control and management with the indebtedness of the company. Three hypotheses were prepared according to the available literature that, once tested, proposed the relationship between indebtedness and each of the possible controllers or managers for each of the companies.

For the application of the method, a sample of 356 companies with accounting data available in the Economatica data base was used, from which it was given the rank of managers, controllers and family members, to be possible to advance in studies on this topic.

For hypothesis testing, it was analyzed various research methods, and the chosen method been the Fixed Effects through the Hausman test. All results were presented throughout this work.

The main results of this research indicate that there is a relationship between family business and family managers and the indebtedness of the company. There was no statistical significance revealed the relation of the family control variable in the indebtedness.

As for the family business, it was observed that there is also a relationship between indebtedness and family businesses and run by family members. All relationships are statistically significant, so we can not reject the hypotheses H1 and H3. This relationship was found negative in both cases, showing a trend of family businesses or run by family members to be less indebted than others, in the selected sample. These evidences confirm the studies of Siqueira (1998), IBGC (2007), Anderson and Reeb (2003), Shleifer and Vishny (1986) among others, that point to a reduction of cost of investments in family businesses, as well as the preference for use of equity.

One cannot state, however, that companies with a family control present a capital structure different from those of non-family control, it is not possible to confirm the hypothesis $\mathrm{H}_{2}$.

Thus, this research indicates that the Brazilian family businesses present, in the sample studied, a smaller indebtedness than those without family influence. 


\subsection{LIMITATIONS OF THE RESEARCH}

It is known that the profile of the manager and the company's culture can influence the decisions of indebtedness. Eventual misclassification may occur in the definition of family control and family management, since they are established by the researcher, and may be raised by other methods in future research. The ambiguity of these classifications will always exist, because the operational definitions are arguments set for this search.

\section{REFERENCES}

AGRAWAL, A.; NAGARAJAN, N. Corporate Capital Structure, Agency Costs, and Ownership Control: The Case of All-Equity Firms. Jornal of Finance, v. 45, p. 1325-31, set. 1990.

AL-AJMI; J.; HUSSAIN, H.A.; AL-SALEH, N. Decisions on capital structure in a Zakat environment with prohibition of riba: the case of Saudi Arabia. The Journal of Risk Finance, vol. 10, n. 5, p. 460-76, 2009.

ANDERSON, R. C.; REEB, D. M. Board Composition: Balancing Family Influence in S\&P 500 Firms. Administrative Science Quarterly, v. 49, n. 2, p. 209-7, jun. 2004.

ANDERSON, R. C.; REEB, D. M. Founding-Family Ownership and Firm Performance: Evidence from the S\&P 500. The Journal of Finance, v. 58, n. 3., p. 1301-28, jun. 2003.

ANDRES, C. Family ownership, financing constraints and investiment decisions. 2009. Disponível em: <http://ssrn.com/abstract=1101453>. Acesso em: 22 ago. 2011.

BAKER, M.; WURGLER, J. Market timing and capital structure. Journal of Finance, v. 57, n. 1, p. 1-32, feb. 2002.

BARROS, L. A. B. de C. Decisões de financiamento e de investimento das empresas sob a ótica dos gestores otimistas e excessivamente confiantes . Tese de Doutorado (Doutorado em Administração) Faculdade de Economia, Administração e Contabilidade da Universidade de São Paulo, 2005.

BERLE, A. A.; MEANS, G. C. The modern corporation and private property. New York: Macmillan, 1932.

BERSON, Y.; OREG, S. e DVIR, T., Organizational culture as a mediator of CEO values and organizational performance. Academy of Management Proceedings, 2005.

BERTUCCI, J. L. D. O.; CAMPOS, E. A. S.; PIMENTEL, T. D.; PEREIRA, R. D.; Mecanismos de Governança e Processos de Sucessão: um estudo sobre a influência dos elementos de governança corporativa na orientação do processo sucessório em uma empresa familiar. Revista Brasileira de Gestão de Negócios, v. 11, p. 152-67, abr/jun. 2009.

BORNHOLDT, W. Governança na empresa familiar. Porto Alegre: Bookman, 2005. 
BOUBAKARI, A.; FEUDJO, J. R. Corporate governance for the best financing choices: An empirical study from family firms in northern cameroon. International Journal of Economics and Finance, v. 2, n. 2, p. 70-7, 2010.

BRITO, G. A. S. ; CORRAR, L. J. ; BATISTELLA, F. D. Fatores determinantes da estrutura de capital das maiores empresas que atuam no Brasil. Revista Contabilidade \& Financas, vol. 18, p. 9-19, 2007.

BURKART, M.; PANUNZI, F.; SHLEIFER, A. Family firms. Journal of Finance, v. 58, n. 9, pp. 2167-201, set. 2003

CARLOCK, R. S; WARD, J. L., Strategic Planning for the Family Business: parallel planning to unify the family and business. Londres: Palgrave, 2000.

COMBS, J.G. Commentary: the servant, the parasite, and the enigma: a tale of three ownership structures and their affiliate directors. Entrepreneurship Theory and Practice, v. 32, no. 6, p. 1027-33, nov. 2008.

DAMI, A. B. T.; ROGERS, P.; RIBEIRO, K. C. de S.; SOUSA, A. F. . Corporate governance and ownership structure in brazil: causes and consequences. Corporate Ownership \& Control. Ukraine, v. 5, n. 2, p. 1-15, 2007.

DEDOUSSIS, E.; PAPADAKI, A. Investment spending and corporate governance. Managerial Finance, v. 36, no. 3, p. 201-24, 2010.

DEMSETZ, H. The structure of ownership and the theory of the firm. Journal of Law and Economics. v. 26, p. 375-94, 1983.

DIAMOND, D. Reputation acquisition in debt markets. Journal of Political Economy. v. 4, n.97, p. 828-62, 1989.

FAMA, E. \& FRENCH, K.. Testing trade-off and pecking order predictions about dividends and debt. The Review of Financial Studies, v. 15, n. 1, p.1-33, 2002.

FAMA, E. F.; JENSEN, M. Separation of ownership and control. Journal of Law and Economics. n. 26, p. 301-25, jun. 1983.

FIEGENBAUM, A.; THOMAS, H. Attitudes toward risk and the risk-return paradox: Prospect theory explanations. Academy of Management Jornal, n. 31, p. 85-109, 1988.

FIEGENER, M. K. Locus of ownership and family involvement in small private firms. Journal of Management Studies, v. 47, n. 2, p. 1467, 2010.

FILATOTCHEV, I.; LIEN, Y.; PIESSE, J. Corporate governance and performance in publicly listed, family-controlled firms: evidence from Taiwan. Asia Pacific Journal of Management, v.22, n.3, p. 257-283, 2005.

FIRTH, M. The impact of institutional stockholders and managerial interest on the capital structure of firms. Managerial and Decision Economics, v. 16, p. 167-75, 1995. 
FORTE, D. Estudo sobre a estrutura de capital das empresas brasileiras no período pós Plano Real (1995-2005). Tese de Doutorado. Universidade Presbiteriana Mackenzie, São Paulo, 2005.

FRIEND, I.; HASBROUCK, J. Determinants of capital structure. Research in Finance. New York, v. 7, p. 1-19, 1987.

FRIEND, I.; LANG, L. An Empirical test of the impact of managerial self- interest on corporate capital structure. Journal of Finance, New York, v. 43, p. 271-81, 1988.

GÓMEZ-MEJÍA, L. R.; HAYNES, K.T.; NÚÑES-NICKEL, M. et al. Socioemotional wealth and business risks in family-controlled firms: evidence from Spanish olive oil mills.

Administrative Science Quarlerly, v. 53, n.1, p. 106-37, dez. 2007.

HADANI, M. Family Matters: Founding family firms and corporate political activity.

Business \& Society, Sage Publications, v., 46, n. 4, p. 395-498, dez. 2007.

HARRIS, M.; RAVIV, A. The theory of capital structure. The Journal of Finance, v. 46, p. 297-355, 1991.

HEINEBERG, R; PROCIANOY, J. L. Aspectos determinantes do pagamento de proventos em dinheiro das empresas com ações negociadas na BM\&FBovespa. In: ENCONTRO BRASILEIRO DE FINANÇAS, 3., 2003.

JENSEN, M.; MECKLING, W. Theory of the firm: managerial behavior, agency costs and ownership structure. Journal of Financial Economics, v. 3, p.305-60, 1976.

JENSEN, M. Agency costs of free-cash-flow, corporate finance, and takeovers. American Economic Review, v. 76, p. 323-29, 1986.

JUNAID-UL-HAQ, NASIR, R. U.,WASIMULLAH. Pecking order and trade-off model: theory vs practice. Interdisciplinary Journal of Contemporary Research in Business, v. 2, n.12, p. 346-57, apr. 2011

KAYO, E. K.; FAMÁ, R. Teoria da agência e crescimento: evidências empíricas dos efeitos positivos e negativos do endividamento. Caderno de Pesquisas em Administração, v. 2, n. 5, p. 2-8, $2^{\circ}$. sem. 1997.

KING, M. R.; SANTOR, E. Family values: ownership structure, performance and capital structure of Canadian firms. Journal of Banking \& Finance, v. 32, p. 2423-32, 2008.

KOTEY, B.; MEREDITH, G. G., Relationships among owner/manager personal values, business strategies, and enterprise performance. Journal of Small Business Management, v. 35, n. 2, p. 12-35, apr. 1997.

LA PORTA, R., LOPEZ-DE-SILANES, F.; SHLEIFER, A. Corporate ownership around the world. Journal of Finance, v. 54, p. 471-517, jan. 1999. 
LANDSTROM, H.; WINBERG, J. Financial bootstrapping in small businesses: examining managers' resource acquisition behaviors. Journal of Business Venturing, n. 16, p. 235-54, 2000 .

LEAVELL, H.; MANIAM, B. A survey of small business debt financing practices. The Business Review, Cambridge, v. 1, n.1, p. 37-42, 2009.

LEE, J. Corporate finance in family business groups. (Doutorado em Finanças) - New York University, 2011.

LONGENECKER, J. G., MOORE, C. W., PETTY, J. W. et al. Administração de pequenas empresas. 13 ed. New York: Thomson, 2007.

LÓPEZ-GRACIA, J.; SÁNCHEZ-ANDÚJAR, S. Financial structure of the family business: evidence from a group of small Spanish firms. Family Business Review, v. 20, n. 4, p. 26987, dec. 2007.

MACHADO, D.G.; ALMEIDA, D.M.; SCARPIN, J.E. Endividamento e lucratividade: um estudo em empresas familiares que compõem o índice IBRX-100 da BM\&FBOVESPA.

Revista Ambiente Contábil, v. 4, n. 3, 2012.

MALMENDIER, U.; TATE, G. A. Who makes acquisitions? A test of the overconfidence hypothesis. Working Paper, set. 2004. Disponível em:

$<$ http://www.stybelpeabody.com/overconfidence.pdf>. Acesso em: 15 dez. 2009.

MARTINS, O; PAULO, E. Reflexo da adoção Das IFRS na análise de desempenho das companhias de capital aberto no Brasil. Revista de Contabilidade e Organizações, v. 4, n. 9, p. 30-54, maio-ago, 2010.

MCCONAUGHY, D.L. Founding-Family-Controlled corporations: An agency-theoretic analysis of corporate ownership structure and its impact upon corporate efficiency, value, and capital structure. 1994. (Doutorado em Finanças) - Universidade de Cincinnati, 1994.

MODIGLIANI, F.; MILLER, M. Corporate income taxes and the cost of capital: A correction. American Economic Review, v. 53, p. 433-43, 1963.

MODIGLIANI, F. \& MILLER, M. The cost of capital, corporation finance and the theory of investment. American Economic Review, v. 48, p. 261-97, 1958.

MOREIRA, M. M.; PUGA, F. P. Como a indústria financia o seu crescimento - uma análise do Brasil pós-real. Revista de Economia Contemporânea, ed. especial, v. 5, p. 35-67, 2000.

MOSEBACH, J. E. Founding family firms: effective tax rates and dividend payout policies. 2007. (Doutorado em Finanças) - University of Arkansas, 2007.

MYERS, S. The capital structure puzzle. Journal of Finance, v. 39, p. 575-92, 1984.

OKIMURA, R. T. Estrutura de propriedade, governança corporativa, valor e desempenho das empresas no Brasil. 2003. 220 f. Dissertação (Mestrado) - Faculdade de Economia, Administração e Contabilidade, São Paulo, Universidade de São Paulo, 2003. 
ORO, I. M.; BEUREN, I. M.; HEIN, N. Análise da relação entre a estrutura de capital e o lucro operacional nas diversas gerações de empresas familiares brasileiras. CONGRESSO BRASILEIRO DE CONTABILIDADE, p. 15-7, jun. 2008. Disponível em:

$<$ http://www.furb.br/congressocont/_files/CCG029.pdf>. Acesso em: 12 ago. 2009.

PEROBELLI, F. , FAMA, R. Determinantes da estrutura de capital: aplicação a empresas de capital aberto brasileiras. Revista de Administração da Universidade de São Paulo, São Paulo, v. 37, p. 52-85, 2002.

PEROBELLI, F.F.C.; SILVEIRA, A.M.; BARROS, L.A.B.C. Fatores determinantes da estrutura de capital: novas evidências no Brasil. In: ENCONTRO BRASILEIRO DE FINANÇAS DA SOCIEDADE BRASILEIRA DE FINANÇAS (SBFIN), 5., São Paulo, 2005.

PINDADO, J.; LA TORRE, C. Financial decisions as determinants of ownership structure: evidence from Spanish family controlled firms. Managerial Finance, v. 34, n. 12, p. 868-85, 2008 .

POPPER, K. R. A lógica da pesquisa científica. 2 ed. São Paulo: Cultrix, 1975.

ROSSATO NETO, F. J.; CAVEDON, N. R. Empresas familiares: desfilando seus processos sucessórios. Cadernos EBAPE, v. 2, n. 3, dez. 2004.

RUBINSTEIN, M. E. A Mean-Variance Synthesis of corporate financial theory. Journal of Finance, v. 28, n. 1, p. 15-22, 1973.

SHLEIFER, A. VISHNY, R. A Survey of corporate governance. Journal of Finance, v. 52, n. 2, p. 737-83, 1997.

SHLEIFER, A.; VISHNY, R. Large shareholders and corporate control, 94 J. Jornal of Economics, Massachusetts Institute of Technology, p. 461-89, 1986.

SCHULZE, W. A.; DINO, R. N. The impact of distribution of ownership on the use of financial leverage in family firms. In: US ASSOCIATION FOR SMALL BUSINESS, 2004.

SIQUEIRA, T. V. Concentração da propriedade nas empresas brasileiras de capital aberto. Revista do BNDES, Rio de Janeiro, v. 5, n. 10, p. 37-62, dez. 1998.

SIRMON, D. G.; HITT, M. A. Managing resources: linking unique resources, management, and wealth creation in family firms. Entrepreneurship: Theory and Practice, v. 4, n. 27, p. 339-58, 2003.

SIRMON, D. G.; ARREGLE, J.; HITT, M. A.; WEBB, J. W. The role of family influence in firms' strategic responses to threat of imitation. Entrepreneurship Theory and Practice, v. 30, n. 10, p. 979-994, nov. 2008.

SOARES, R. O., KLOECKNER, G. O. Endividamento em firmas com alta propensão à expropriação: o caso de firmas com um controlador. Revista de Administração de Empresas (RAE), São Paulo, v. 48, n. 4, p. 73-96, out.-dez. 2008. 
STIGLITZ, J. E. A Re-examination of the modigliani-miller theorem. American Economic Review, v. 59, n. 5, p. 368, 1968.

STULZ, R. Managerial discretion and optimal financing policies. Journal of Financial Economics, v, 26, p. 3-27, 1990.

THALER, R.; BARBERIS, N. A survey of behavioral finance. In: CONSTANTINIDES, G.; HARRIS, M.; STULZ, R. (Orgs.). Handbook of the economics of finance. New York: North Holland, 2003.

THOMSEN, S., PEDERSEN, T. European ownership concentration: causes and consequences. Institute of International Economics and Management. Copenhagen: Copenhagen Business School, 1997.

TITMAN, S.; WESSELS, R. The determinants of capital structure choice. Journal of Finance, v. 43, n. 1, p. 1-19, 1988.

TONNETO FILHO, V.; FREGONESI, M. S. F. A. Análise da variação nos índices de Endividamento e liquidez e Do nível de divulgação das empresas do setor de alimentos processados com a adoção das normas internacionais. In: CONGRESSO USP DE CONTROLADORIA E CONTABILIDADE, São Paulo, 2010.

ZAHA, S. A. et al. Culture of family commitment and strategic flexibility: the moderating effect of stewardship. Entrepreneurship Theory and Practice, p. 1035-54, nov. 2008. 